Огляди літератури, оригінальні дослідження, погляд на проблему, ювілеї

УДК 616.831-085+616.12-008.331.1-085

DOI 10.11603/1811-2471.2019.v0.i1.10052

\title{
ХРОНІЧНА ЦЕРЕБРАЛЬНА ВЕНОЗНА ДИСФУНКЦІЯ: ПОШИРЕНІСТЬ ТА ФАКТОРИ РИЗИКУ
}

\author{
๑О. Є. Коваленко, Н. Г. Притико
}

Національна медична академія післядипломної освіти імені П. Л. Шупика,

Державна наукова установа «Науково-практичний центр профілактичної та клінічної медецини»

Державного управління справами,

Філія № 1. Комунальне некомерційне підприємство «Консультативно-діагностичний центр»

Святошинського районум. Києва

РЕЗЮМЕ. На сьогодні проблема лікування та верифікації діагнозу у хворих із синдромом хронічної венозної церебральної дисфункції (СХВЦД) є одним із важливих питань прийому лікаря-невролога.

Мета - визначити частку хворих із СХЦВД у межах неврологічного амбулаторного прийому невролога та виявити основні чинники ризику патології залежно від гендерних та вікових показників.

Матеріал і методи. Загальноклінічне та клініко-неврологічне обстеження хворих амбулаторного прийому лікаря-невролога міської поліклініки за рік, виділення групи пацієнтів (95 осіб віком від 30 до 65 років) із клінічними ознаками СХЦВД з деталізацією анамнезу та визначенням ймовірних модифікованих та немодифікованих факторів ризику (ФР) появи патології. Хворі були розподілені на 3 вікові групи: 30-44, 45-60, 60-65 років та на 2 гендерні.

Результати. Оцінка кількості та характеру звернень на прийомі невролога поліклініки за 2018 рік показала, що з усієі кількості випадків цереброваскулярної патології дещо більше половини складають хворі із СХЦВД, або майже третину від усієї кількості хворих (33,8 \%).

Найбільш значущою причиною, з якою загальний контингент хворих пов'язував появу СХЦВД, було статичне перевантаження, дещо меншою (всього на 2 \%) - фізичне перевантаження, майже в рівних частках - черепномозкові травми, стрес та спадковість за материнською лінією, наступними майже рівними чинниками були спадковість за батьківською лінією та клімакс.

Спостерігаються певні достовірні гендерні відмінності щодо чинників, з якими хворі пов'язують появу СХЦВД. Статичне перевантаження для чоловіків у 2,6 раза менш значуще, ніж фізичне навантаження, тоді як у жінок - у 1,5 раза частіше, й саме його вказано як основну причину виникнення патології. у чоловіків спадковість за материнською та батьківською лініями достовірно не відрізнялась $(p>0,05)$, тоді як у жінок лінія матері мала тенденцію до остаточної переваги $(p=0,1)$.

Висновок. Різні вікові періоди хворих мали свої особливості щодо появи модифікованих та немодифікованих ФР: фізичне навантаження переважало у віковий період 45-59 років, статичне навантаження та легка чМТ від 30 до 59 років, в цей же віковий період було виявлено негативну спадковість. У кожній віковій групі достовірна різниця між жінками та чоловіками $(p<0,05)$ мала місце: стосовно фізичного навантаження - в 18-29 років; статичного навантаження - в 45-59; ЧМТ - в 60+; стресу - в 30-44 років. Тенденція р<0,1 стосувалася фактора «клімакс" у період 45-59 років. Перспективним є врахування модифікованих факторів ризику в розробці профілактичних заходів щодо СХЦВД.

КЛючовІ СлОВА: цереброваскулярна патологія; синдром хронічної церебральної венозної дисфункції (СХЦВД); гендерні особливості; вік хворих; артеріальний тиск.

Вступ. Судинна патологія мозку - одна із найактуальніших проблем сучасної медицини через характер ускладнень, що супроводжуються високим рівнем інвалідизації, смертності та зниженням якості життя. Зазвичай переважну увагу в клінічній медицині віддають артеріальним змінам церебрального кровотоку. Венозні порушення церебрального кровообігу, що позначаються як синдром хронічної церебральної венозної дисфункції (СХЦВД), на жаль, вивчаються менше, ймовірно, через складнощі об'єктивної верифікації порушень $[1,2,3,4]$.

СХЦВД - одна з найчастіших причин звертання хворих за допомогою до лікаря, перш за все, на амбулаторний прийом невролога та сімейного лікаря. На жаль, патологія значною мірою має не- специфічні прояви, тому її виявлення та пошук причинних факторів має велике практичне значення.

Мета дослідження - визначити частку хворих із СХЦВД в межах неврологічного амбулаторного прийому невролога та виявити основні чинники ризику патології залежно від гендерних та вікових показників.

Матеріал і методи дослідження. Загальноклінічне та клініко-неврологічне обстеження хворих амбулаторного прийому лікаря-невролога міської поліклініки за рік, виділення групи пацієнтів (95 осіб віком від 30 до 65 років) із клінічними ознаками СХЦВД з деталізацією анамнезу та визначенням ймовірних модифікованих та немодифікованих факторів ризику (ФР) появи патології. 
Огляди літератури, оригінальні дослідження, погляд на проблему, ювілеї

Хворі були розподілені на 3 вікові групи: 30-44, 45-60, 60-65 рр. та на 2 гендерні.

Результати й обговорення. Наш підрахунок кількості нозологій на прийомі невролога поліклініки за 2018 рік показав, що судинні захворювання нервової системи (наслідки інсультів, хронічні порушення мозкового кровообігу) мали місце у близько двох третин від усієї кількості хворих. Натомість, з усієї кількості цереброваскулярної патології дещо більше половини складає СХЦВД (рис. 1). Цікаво, що первинне звернення до невро- лога часто не виглядає як скарга цереброваскулярного характеру, хворий скаржиться на стійкий головний біль, та/або безсоння, та/або загальну слабкість, та/або запаморочення, що пов'язує або з наслідками навіть нетяжкої черепно-мозкової травми, нерідко пацієнти звертаються до невролога після безуспішної терапії у сімейного лікаря, де венозні порушення хоча й часто зустрічаються, але не розпізнаються через суттєву кількість неспецифічних проявів та недостатній рівень можливостей верифікації патології.

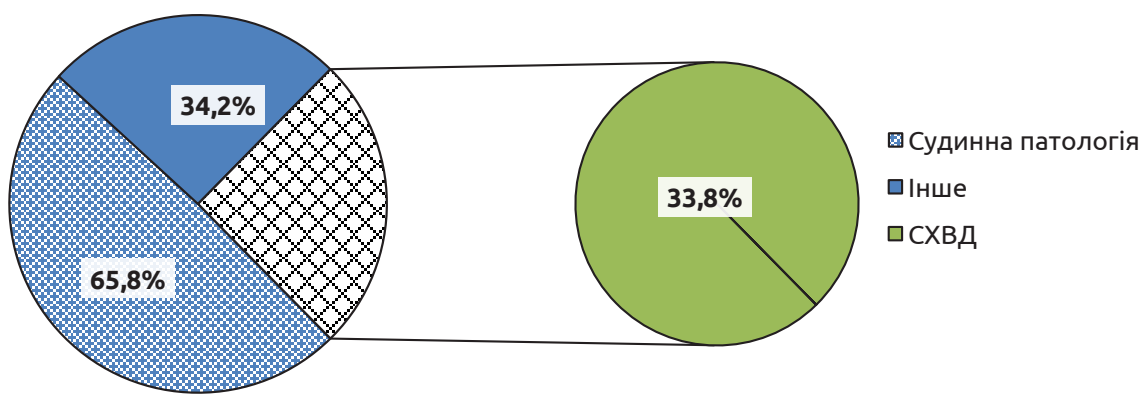

Рис. 1. Розподіл хворих за патологією - причиною звернення до лікаря.

Аналіз головних причин, з якими пацієнти, за нашим опитуванням, пов'язують виникнення СХЦВД - статичне та/або фізичне перевантаження, стрес, легкі черепно-мозкові травми (переважно гіперекстензійного характеру), спадко- вість, клімактеричний період, пологи (у матері) тощо.

За нашими даними, рейтинг виявлених причин, з якими пацієнт пов'язує виникнення СХЦВД, виглядає таким чином (рис. 2).
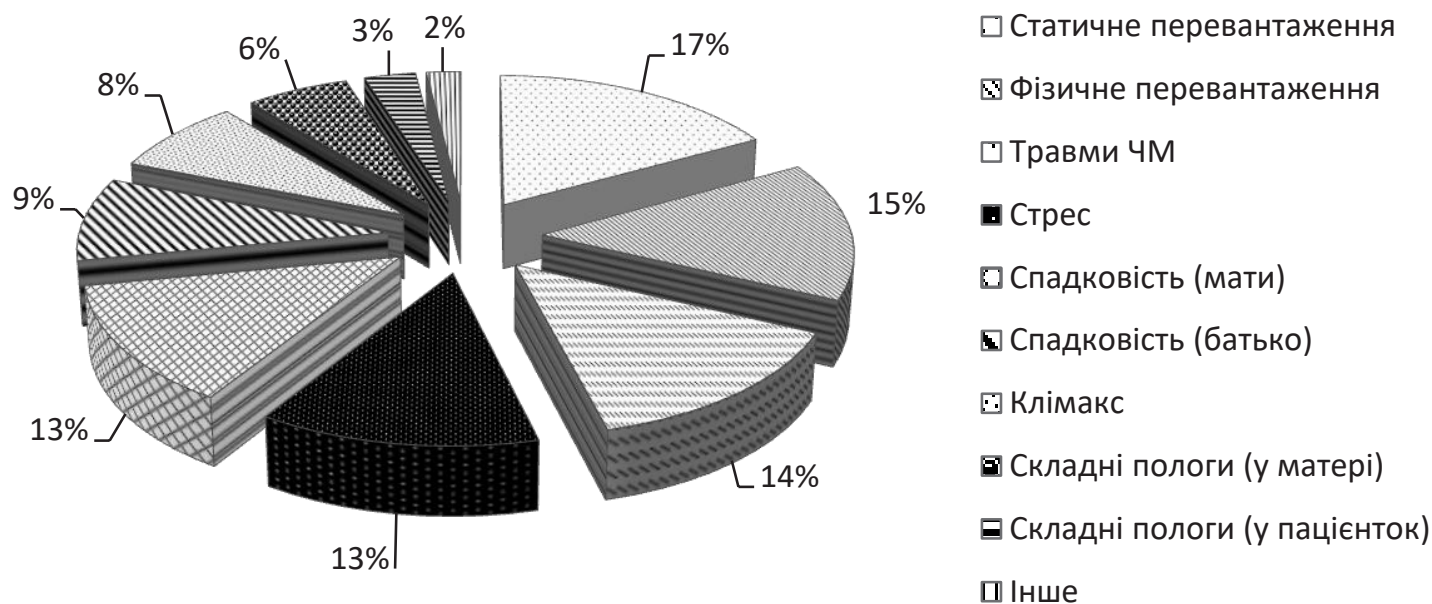

Рис. 2. Основні причини СХЦВД у загального контингенту досліджуваних хворих.

Як показано на діаграмі (рис. 2), найбільш значущою причиною, з якою пацієнт пов'язує появу СХЦВД, у загальному контингенті хворих було статичне перевантаження, що пояснюється характером діяльності людини, дещо меншою (всього на 2 \%) - фізичне перевантаження, майже в рівних частках - черепно-мозкові травми, стрес та спадковість за материнською лінією, наступни- ми майже рівними чинниками були спадковість за батьківською лінією та клімакс.

Стосовно гендерних показників спостерігали відмінності причинних чинників у жінок та чоловіків (рис. 3, 4).

Як видно з діаграми, серед жіночого контингенту так само, як і в загальній групі, переважало статичне перевантаження (майже п'ята частина від 
Огляди літератури, оригінальні дослідження, погляд на проблему, ювілеї

усіх досліджуваних жінок), на другому місці - спадковість за материнською лінією, решта - майже в однакових пропорціях (послідовно з різницею в 1 \%) фізичне перевантаження, ЧМТ, стрес, а також далі в порядку спадання спадковість за лінією батька та клімакс, пологи матері, тяжкі особисті пологи та ін. (рис. 4).

Показники у чоловіків мали іншу картину

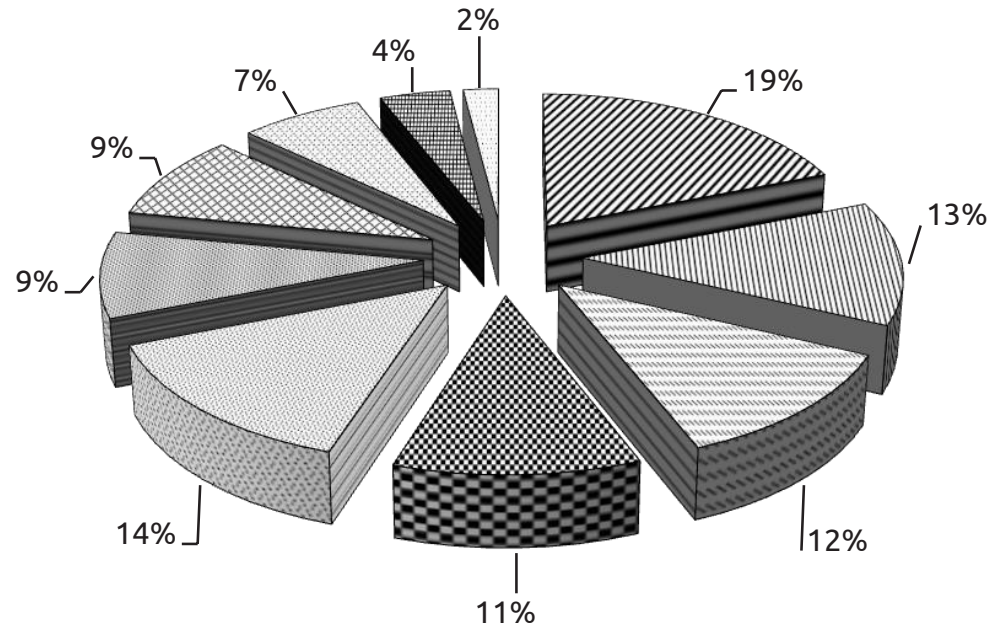

च Статичне перевантаження

Ф Фізичне перевантаження

๑Травми ЧМ

曰Стрес

๒ Спадковість (мати)

๑ Спадковість (батько)

๑ Клімакс

๑Складні пологи (у матері)

¥Складні пологи (у пацієнток)

口Інше

Рис. 3. Основні причини СХЦВД у жіночого контингенту досліджуваних хворих.

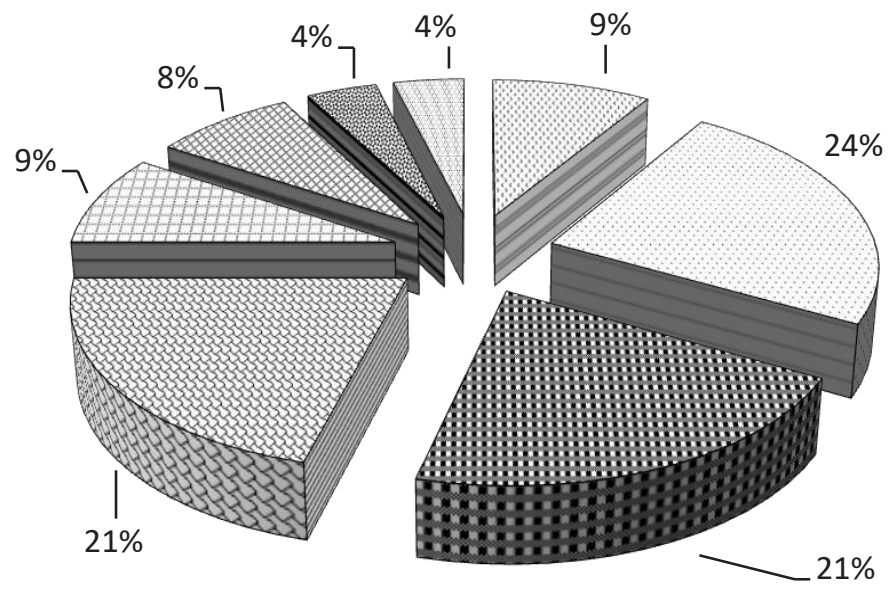

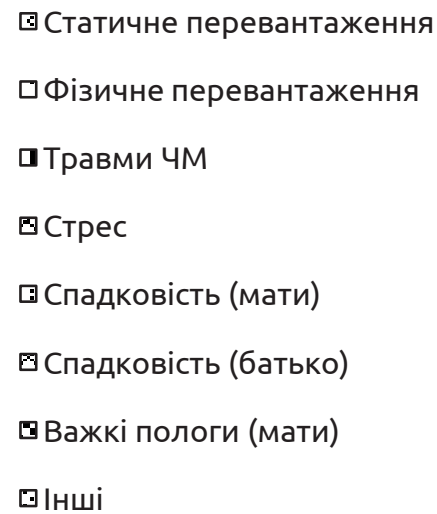

Рис. 4. Основні причини СХЦВД у чоловічого контингенту досліджуваних хворих.

Діаграма відображає факт, що найчастішим чинником, з яким чоловіки пов'язують появу СХЦВД, є нетяжка ЧМТ (нагадаємо, що хворих 3 наслідками тяжких та середніх ЧМТ у дослідження не включали) - майже чверть від усіх випадків. У рівних частинах - близько п'ятої частки кожна стрес та фізичне перенавантаження. Дещо менше десятої частини від загалу займають статичне перевантаження, спадковість по батьківській та материнській лініях.

Цікавим, на наш погляд, $є$ й чинники, притаманні різним віковим періодам (табл. 1).

Отже, достовірну різницю $(p<0,05)$ між жінками та чоловіками спостерігали за наявності таких факторів, як фізичне перевантаження $(p=0,04)$ та легкі черепно-мозкові травми $(p=0,045)$. На рівні тенденції $(p<0,1)$ різняться статичне навантаження $(p=0,086)$, клімакс $(p=0,086)$ та стрес $(p=0,078)$.

Як відображено в таблиці, фізичне навантаження переважало у віковий період 45-59 років, статичне навантаження та легка ЧМТ - від 30 до 59 років, в цей же віковий період негативна спадковість. У кожній віковій групі початку захворювання достовірна різниця між жінками та чоловіками $(p<0,05)$ мала місце: стосовно фізичного навантаження - в 18-29 років; статичного навантаження в 45-59; ЧМТ - в 60+; стресу - в 30-44 роки. Тенденція р<0,1 стосувалася фактора "клімакс» у період 45-59 років. 
Огляди літератури, оригінальні дослідження, погляд на проблему, ювілеї

Таблиця 1. Гендерні особливості факторів ризику СХЦВД в різні вікові періоди

\begin{tabular}{|c|c|c|c|c|c|c|c|c|c|c|c|c|}
\hline ১̊ & 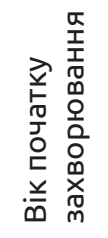 & 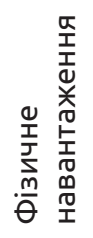 & 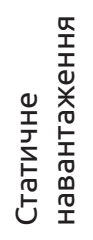 & 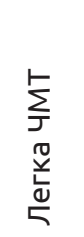 & 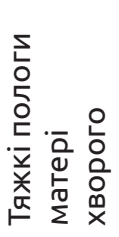 & 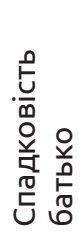 & 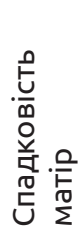 & 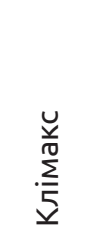 & $\begin{array}{l}\stackrel{\Xi}{\Xi} \\
\stackrel{\Xi}{\Xi}\end{array}$ & 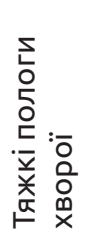 & 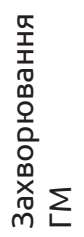 & 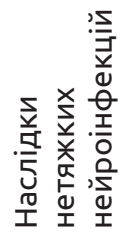 \\
\hline \multirow{5}{*}{$\begin{array}{l}\stackrel{\vec{v}}{\underline{\underline{x}}} \\
\text { 妾 }\end{array}$} & $18-29$ & 0,0 & 2,8 & 0,9 & 0,5 & 1,4 & 0,9 & 0,0 & 2,3 & 0,5 & 0,0 & 0,5 \\
\hline & $30-44$ & 2,3 & 8,8 & 5,6 & 3,7 & 3,7 & 6,0 & 1,9 & 2,3 & 2,8 & 0,5 & 0,5 \\
\hline & $45-59$ & 8,8 & 7,9 & 4,2 & 2,3 & 3,7 & 6,9 & 6,5 & 6,5 & 0,5 & 0,5 & 0,5 \\
\hline & $60+$ & 1,9 & 0,0 & 0,0 & 0,5 & 0,5 & 0,5 & 0,5 & 0,5 & 0,0 & 0,0 & 0,0 \\
\hline & & 13,0 & 19,4 & 10,6 & 6,9 & 9,3 & 14,4 & 8,8 & 11,6 & 3,7 & 0,9 & 1,4 \\
\hline \multirow{5}{*}{ 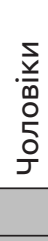 } & $18-29$ & $1,9 *$ & 1,9 & 3,8 & 0,0 & 0,0 & 1,9 & 0,0 & 0,0 & 0,0 & 0,0 & 0,0 \\
\hline & $30-44$ & 5,7 & 7,5 & 7,5 & 1,9 & 3,8 & 1,9 & 0,0 & $11,3 *$ & 0,0 & 0,0 & 0,0 \\
\hline & $45-59$ & 13,2 & 0,0 * & 7,5 & 1,9 & 3,8 & 3,8 & $0,0 * *$ & 7,5 & 0,0 & 0,0 & 1,9 \\
\hline & $60+$ & 3,8 & 0,0 & $1,9 *$ & 0,0 & 0,0 & 1,9 & 1,9 & 1,9 & 0,0 & 0,0 & 0,0 \\
\hline & & 24,5 & 9,4 & 20,8 & 3,8 & 7,5 & 9,4 & 1,9 & 20,8 & 0,0 & 0,0 & 1,9 \\
\hline \multicolumn{2}{|c|}{$\begin{array}{c}\text { р між Ж і ч, } \\
\text { фактор в } \\
\text { цілому }\end{array}$} & \begin{tabular}{l}
\multirow{2}{0}{} \\
0 \\
II \\
0
\end{tabular} & $\begin{array}{l}0 \\
0 \\
0 \\
0 \\
11 \\
0\end{array}$ & $\begin{array}{l}\text { nn } \\
\text { o } \\
0 \\
\text { II } \\
0\end{array}$ & $\begin{array}{l}\forall \\
0 \\
0\end{array}$ & $\begin{array}{l}\infty \\
0 \\
0 \\
11 \\
0\end{array}$ & $\begin{array}{l}\pi \\
m \\
0 \\
11 \\
0\end{array}$ & $\begin{array}{l}0 \\
0 \\
0 \\
0 \\
11 \\
0\end{array}$ & $\begin{array}{l}\infty \\
\text { o } \\
0 \\
0 \\
11 \\
0\end{array}$ & $\begin{array}{l}\text { nn } \\
\text { ñ } \\
\text { In } \\
11 \\
0\end{array}$ & $\begin{array}{l}\infty \\
\infty \\
\vdots \\
\vdots \\
\text { II } \\
0\end{array}$ & $\begin{array}{l}\infty \\
\infty \\
0 \\
0 \\
11 \\
0\end{array}$ \\
\hline
\end{tabular}

Примітка: * - відмінність між жінками та чоловіками у відповідній віковій групі $\epsilon$ статистично значущою, p<0,05; ** - відмінність між жінками та чоловіками у відповідній віковій групі $\epsilon$ статистично значущою, p<0,1.

Висновки. 1. Оцінка кількості та характеру звернень до невролога поліклініки за 2018 рік показала, що з усієї кількості випадків цереброваскулярної патології дещо більше половини складають хворі з СХЦВД, або майже третину від усієї кількості пацієнтів (33,8\%).

2. Найбільш значущою причиною, з якою загальний контингент хворих пов'язував появу СХЦВД, було статичне перевантаження, дещо меншою - фізичне перенавантаження, майже в рівних частках - черепно-мозкові травми, стрес та спадковість за материнською лінією, наступними майже рівними чинниками були спадковість за батьківською лінією та клімакс.

3. Відзначено певні достовірні гендерні відмінності щодо чинників, з якими хворі пов'язують появу СХЦВД. Статичне перевантаження для чоловіків у 2,6 раза менш значуще, ніж фізичне навантаження, тоді як у жінок статичне навантаження у 1,5 раза частіше, й саме його вказано як ос- новну причину виникнення патології. У чоловіків спадковість за материнською та батьківською лініями достовірно не відрізнялась $(p>0,05)$, тоді як у жінок лінія матері мала тенденцію до остаточної переваги $(p=0,1)$.

4. Різні вікові періоди хворих мали свої особливості щодо появи модифікованих та немодифікованих ФР: фізичне навантаження переважало у віковий період 45-59 років, статичне навантаження та легка ЧМТ - від 30 до 59 років, в цей же віковий період було виявлено негативну спадковість. У кожній віковій групі достовірна різниця між жінками та чоловіками $(p<0,05)$ мала місце: стосовно фізичного навантаження - в 18-29 років; статичного навантаження - в 45-59; ЧМТ - в 60+; стресу - в 30-44 роки. Тенденція p<0,1 стосувалася фактора "клімакс» у період 45-59 років.

Перспективи подальших досліджень. Врахування модифікованих факторів ризику в розробці профілактичних заходів щодо СХЦВД.

\section{ЛІТЕРАТУРА}

1. Бердичевский М. Я. Венозная дисциркуляторная патология головного мозга / М. Я. Бердичевский. - М. : Медицина, 1989.

2. Шемагонов А. В. Синдром хронической цере6ральной венозной дисциркуляции / А. В. Шемагонов // Укр. мед. часопис. - 2007. - Т. 5 (61). - С. 33-36.

3. Приходько В. Ю. Синдром хронічної венозної дисциркуляції головного мозку / В. Ю. Приходько, Д. О. Кашковський. - К. : Семейная медицина, 2013. № $5 .-$ С. 65-72.

4. Кузнецов В. В. Особенности диагностики и лечения венозной энцефалопатии /В.В.Кузнецов, Д. В. Шульженко//The Journal of Neuroscience of B.M. Mankovskyi.2015. - T. 3, № 1. - C. 97-104. 
Огляди літератури, оригінальні дослідження, погляд на проблему, ювілеї

\section{REFERENCES}

1. Berdichevskiy, M.Ya. (1989). Venoznaya distsirkulyatornaya patologiya golovnogo mozga [Venous dyscirculatory pathology of the brain]. Moscow: Meditsina [in Russian].

2. Shemagonov, A.V. (2007). Sindrom khronicheskoy tserebralnoy venoznoy distsirkulyatsii [Syndrome of chronic cerebral venous discirculation]. Ukrainskyi medychnyi chasopys - Ukrainian Medical Journal, 5 (61)-ÍKH-KH, 33-36 [in Russian].
3. Prykhodko, V.Yu., \& Kashkovskyi, D.O. (2013). Syndrom khronichnoi venoznoi dystsyrkuliatsii holovnoho mozku [Syndrome of chronic venous circulation of the brain]. Kyiv: Semeynaya meditsina, 5, 65-72 [in Russian].

4. Kuznetsov, V.V., \& Shulzhenko, D.V. (2015). Osobennosti diagnostiki i lecheniya venoznoy entsefalopatii [Features of diagnosis and treatment of venous encephalopathy]. The Journal of Neuroscience of B.M. Mankovskyi, 3, 1, 97-104 [in Russian].

\title{
ХРОНИЧЕСКАЯ ЦЕРЕБРАЛЬНАЯ ВЕНОЗНАЯ ДИСФУНКЦИЯ: РАСПРОСТРАНЕННОСТЬ И ФАКТОРЫ РИСКА
}

\author{
๑А. Е. Коваленко, Н. Г. Притыко
}

Национальная медицинская академия последипломного образования имени П. Л. Шупика Государственное научное учреждение «Научно-практический центр профилактической клинической медицины» Государственного управления делами

Филиал №1. Комунальное некомерческое предприятие «Консультативно-диагностический центр» Святошинского района г. Киева

РЕЗЮМЕ. Сегодня проблема лечения и верификации диагноза у пациентов с синдромом хронической церебральной венозной дисфункции является одним из актуальных вопросов приема невролога.

Цель - определить долю пациентов с синдромом хронической венозной церебральной дисфункции (СХЦВД) в пределах амбулаторного приема невропатолога и выявить основные факторы риска возникновения патологии в зависимости от пола и возраста.

Материал и методы. Общеклиническое и клинико-неврологическое обследование амбулаторно-поликлинических больных, посещающих невролога городской поликлиники в течение года, выделение группы пациентов (95 пациентов в возрасте от 30 до 65 лет) с клиническими признаками СХЦВД с детализацией анамнеза и выявлением вероятных модифицированых и немодифицированых факторов риска появления патологии. Пациенты были разделены на 3 возрастные группы: 30-44, 45-60, 60-65 лет и 2 гендерные.

Результаты. Оценка количества и характера обращений на приеме невролога в поликлинике в 2018 году показала, что из общего числа больных цереброваскулярными заболеваниями чуть более половины - это пациенты с СХЦВД, или почти треть всех пациентов (33,8 \%).

Наиболее значимой причиной, с которой общий контингент пациентов связивал появление СХЦВД, была статическая перегрузка, несколько меньшей (только 2 \%) - физическая перегрузка, почти равные в пропорции черепно-мозговая травма, стресс и наследственность по материнской линии, следующими почти равными факторами были наследственность по линии отца и климакс.

Существуют некоторые существенные гендерные различия в отношении факторов, с которыми пациенты связывают появление СХЦВД. Статическая перегрузка у мужчин в 2,6 раза менее значительна, чем физическая активность, тогда как у женщин она в 1,5 раза чаще, и это указывается в качестве основной причины патологии. У мужчин наследственность по материнской и отцовской линиям существенно не различалась (р>0,05), тогда как у женщин линия матери имела явное преимущество $(p=0,1)$.

Выводы. Разные возрастные периоды пациентов имели свои особенности в отношении появления модифицированных и немодифицированных ФР: физическая нагрузка была распространена в возрасте 45-59 лет, статическая нагрузка и легкая черепно-мозговая травма - от 30 до 59 лет, в течение того же возрастного периода была выявлена негативная наследственность. В каждой возрастной группе разница между женщинами и мужчинами была достоверной ( $<0,05)$ : по отношению к физической нагрузке - 18-29 лет; статической нагрузке - в 45-59; ЧМТ - в 60+; стресс - в 30-44 года. Тенденция р <0,1 была связана с «климаксным» фактором в период 45-59 лет.

Перспективным будет учитывание модифицированных факторов риска при разработке профилактических мер по СХЦВД.

КЛЮчЕВЫЕ СЛОВА: цереброваскулярная патология; синдром хронической церебральной венозной дисфункции (СХЦВД); гендерные особенности; возраст больных; артериальное давление. 


\title{
Огляди літератури, оригінальні дослідження, погляд на проблему, ювілеї
} CHRONIC CEREBRAL VENOUS DYSFUNCTION: PREVALENCE AND RISK FACTORS

\author{
P. Shupyk National Medical University of Postgraduate Education \\ State Scientific Institution "Scientific and Practical Center for Preventive and Clinical Medicine" \\ of the State Administration \\ Branch No. 1. Communal non-commercial enterprise "Consultative-diagnostic Center" \\ of Sviatoshynskyi district of Kyiv
}

SUMMARY. Today, the problem of treatment and verification of a diagnosis in patients with chronic venous cerebral dysfunction syndrome is one of the important issues of receiving a neurologist.

The aim of the study - to determine the proportion of patients with chronic cerebral venous dysfunction (CCVD) within the neurological outpatient admission of the neurologist and identify the main risk factors for the pathology, depending on gender and age.

Material and Methods. General Clinical and Clinical and Neurological Survey of Outpatient Patients Receiving the Neurologist of a City Polyclinic for a year, the allocation of a group of patients (95 patients aged 30 to 65 years) with clinical signs of CCVD with a history of anamnesis and the identification of probable modified and unmodified risk factors pathology. The patients were divided into 3 age groups: 30-44, 45-60, 60-65 and 2 gender groups.

Results. Estimation of the number and nature of appeals in the reception of a polyclinic neurologist for 2018 showed that of the total number of cases of cerebrovascular disease, a little more than half are patients with CCVD, or almost one third of all patients (33.8\%). The most significant causes with which the overall contingent of patients associated with the appearance of CCVD was static overload, somewhat less (only $2 \%$ ) - physical overload, almost equal in proportion - cranial trauma, stress and heredity in the maternal line, followed by almost equal factors were inheritance for the father's line and climax. There are some significant gender differences regarding the factors with which the patients associate the appearance of the CCVD. Static overload for men is 2.6 times less significant than physical activity, whereas in women it is 1.5 times more often, and it is indicated as the main cause of the pathology. In men, heredity in maternal and parental lines did not differ significantly ( $p>0.05)$, whereas in women the line of mother tended to a definitive advantage $(p=0.1)$. Different age periods of patients had their own peculiarities with regard to the appearance of modified and unmodified FR: physical activity was prevalent in the age of 45-59 years, static loading and TBI - from 30 to 59 years, during the same age period, a negative heredity was realized. In each age group, the difference between women and men was significant $(p<0.05)$ in relation to exercise - 18-29 years; static load - in 45-59; TBI - at 60+; stress - in the 30-44 years. The trend of $p<0.1$ was related to the "climax" factor in the period of 45-59 years. It is promising to take into account modified risk factors in the development of preventive measures for the CCVD.

KEY WORDS: cerebrovascular pathology; chronic cerebral venous dysfunction syndrome (CCVD); gender features; patient's age; blood pressure. 